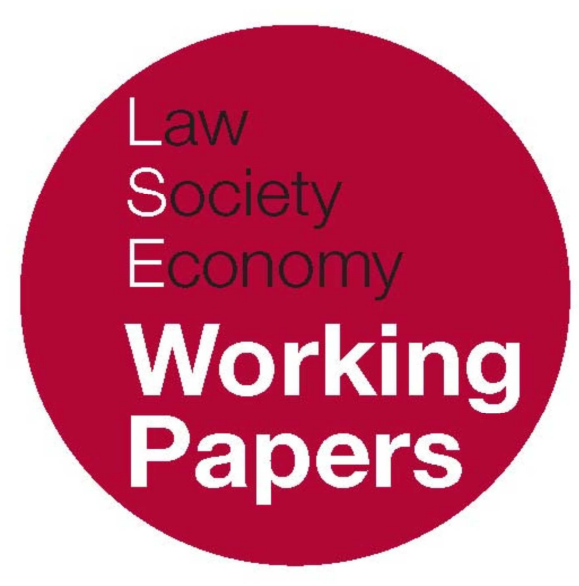

\title{
Multilayered International Parliamentarism:
}

\section{The Case of EU-Brazil Relations}

\author{
Davor Jancic \\ LSE Law, Society and Economy Working Papers 17/2014 \\ London School of Economics and Political Science \\ Law Department
}

This paper can be downloaded without charge from LSE Law, Society and Economy Working Papers at: www.lse.ac.uk/collections/law/wps/wps.htm and the Social Sciences Research Network electronic library at: http://ssrn.com/abstract $=2457871$.

(C) Davor Jancic. Users may download and/or print one copy to facilitate their private study or for non-commercial research. Users may not engage in further distribution of this material or use it for any profit-making activities or any other form of commercial gain. 


\title{
Multilayered International Parliamentarism:
}

\author{
The Case of EU-Brazil Relations
}

\author{
Davor Jancic ${ }^{*}$
}

\begin{abstract}
Challenging the predominant scholarly focus on international parliamentary institutions as the sole and sufficient object of inquiry into the global role of parliaments, this article argues that international interparliamentary relations do not occur merely within isolated forums, but may and do de facto evolve in layers of overlapping forums whenever circumstances allow it. This article conceptualises multilayered international parliamentarism as developing in webs of formal and informal linkages between the same parliamentary institutions in a variety of bilateral and multilateral frameworks regarding the same region. To this end, I conduct an in-depth case study of bilateral and multilateral relations between the parliaments of the EU and Brazil through the lens of institutional arrangements as well as by examining the reaction of the Brazilian and certain other Latin American parliaments to the EU's Returns Directive. The analysis shows that intensified international contacts among parliamentarians accentuate the deliberative function of parliaments and foster their 'diplomatic' actorship in foreign affairs in a concerted attempt to counterbalance globalisation-propelled 'negotiated democracy' nurtured by intergovernmental and transgovernmental ways of doing politics and making law.
\end{abstract}

\footnotetext{
* Dr Davor Jancic is a British Academy Newton Fellow based at the Department of Law, London School of Economics and Political Science. Research for this article was funded by the British Academy through its postdoctoral Newton International Fellowship scheme. Earlier versions of this article were presented at the $8^{\text {th }}$ Pan-European Conference on International Relations, University of Warsaw, 18-21 September 2013 and at the European Union in International Affairs IV Conference, Brussels, $22-24$ May 2014. The author is grateful to Damian Chalmers, Panos Koutrakos, Fredrik Ponjaert and the conference participants for their very constructive feedback. Contact: d.jancic@lse.ac.uk.
} 


\section{INTRODUCTION: GLOBALISING THE ROLE OF PARLIAMENTS}

In democracies, parliaments embody the principle of popular representation, thus ensuring that decisions made by their political community are infused with the interests, preferences and values of the electorate. Parliaments' key role is to make legislation, adopt a budget and keep the executive in check as regards both policy making and implementation of law. Domestic politics and lawmaking are therefore the core of parliamentary business worldwide. However, the role of parliaments is gradually changing due to a variety of factors occurring in the last couple of decades. Globalisation has brought domestic and foreign policy much closer together. Concomitantly, the many projects of regional integration on virtually all continents incorporate some form of parliamentary body. This article analyses these contemporary phenomena through a detailed case study of the relations between the EU and Brazil and of their parliaments' individual and collective entanglement in the adoption of the EU's Returns Directive. The objective is to demonstrate that multilayered international parliamentarism operates not only within the EU, as the world's most fertile site for interparliamentary cooperation, but also on the global stage and in less obvious situations.

International parliamentarism, as a phenomenon whereby parliaments take an active part in world affairs and perform a plethora of activities beyond the constitutional confines of their legal orders, is a curious one for several reasons. Indeed, Šabic rightly questions why parliamentarians engage in this type of action despite the sheer number of disincentives, which are rooted in the constituencyoriented, local or even parochial nature of their work. ${ }^{1}$ In her New World Order, Slaughter speaks of legislative networks as weak forums with little influence precisely because of parliamentarians' electoral 'dependence', whereby they are elected to defend the interests of their voters and not the interests of the voters of other countries, regions and entities. Therefrom flow the other constraints such as lack of benefit for re-election, lack of time due to the need to focus on domestic matters, quick turnover of parliamentarians in and out of office following electoral cycles, and low visibility of their international efforts. ${ }^{2}$

Even so, most authors view international parliamentarism as positive and desirable. For Šabic parliamentarians acting globally add democratic legitimacy and transparency to international affairs by resorting to institutional pressure, persuasion and advocacy in order to promote their positions. ${ }^{3}$ They thereby stimulate public debate and facilitate the development of shared norms and values

\footnotetext{
1 Z. Šabic, 'Building Democratic and Responsible Global Governance: The Role of International Parliamentary Institutions' (2008) 61 Parliamentary Affairs, 256.

2 A.-M. Slaughter, $A$ New World Order (Princeton: Princeton University Press, 2004), 105.

3 Šabic, 'Building Democratic and Responsible Global Governance: The Role of International Parliamentary Institutions' (2008), 255 and 258.
} 
in an interdependent world. ${ }^{4}$ Slaughter, for her part, argues that the legislators' role need not be to directly affect international policy making but can also be to enhance their monitoring of the international activity of the executive branch. ${ }^{5}$ They may also engage in capacity building through training and technical assistance programmes. ${ }^{6}$ Importantly, she views international parliamentary institutions (IPIs) both as catalysts, sparking further integration or facilitating the removal of trade barriers, and as correctives, rectifying the imbalances created by executive dominance in international affairs. ${ }^{7}$ In this vein, Kraft-Kasack accurately observes that while policy outputs are improved through political internationalisation, the democratic legitimacy of such processes is acutely deficient. ${ }^{8}$ She argues that transnational parliamentary assemblies only marginally reduce the democratic deficit of international governance, due to their aloofness from the public, insufficient incorporation of their work in domestic parliaments and various institutional shortcomings that hamper constancy and coherence of their work, such as understaffed secretariats and the lack of permanent delegations. ${ }^{9}$ Despite this, she concludes that transnational parliamentary assemblies may 'contribute to the formation of a transnational public sphere'. ${ }^{10}$ Cutler, too, maintains that IPIs have a 'special communicative role in world society. ${ }^{11}$ Similarly, Malamud and Stavridis submit that even though regional integration parliaments more often than not fail to carry out distinctive parliamentary functions, they aid intraregional communication and nurture a shared regional identity among political elites. ${ }^{12}$ Yet the existing literature treats international parliamentarism as a standalone integrative force without paying heed to the diversity of underlying relations between their members across various forums.

This article argues that international interparliamentary relations do not occur merely within isolated forums, but may and do de facto evolve in layers of overlapping forums whenever circumstances allow it. I dub this phenomenon

\footnotetext{
4 Z. Šabic, 'Democracy across Borders: Parliamentarians and International Public Spheres' (2008) 15 Javnost-The Public, 77.

5 Slaughter, A New World Order (2004), pp.122 and 129. It has similarly been argued that international parliamentarism may help to prevent lethargy and non-responsiveness of governmental actors. See Šabic, 'Democracy across Borders: Parliamentarians and International Public Spheres' (2008), 80.

${ }^{6}$ A.-M. Slaughter and W. Burke-White, 'The Future of International Law is Domestic (or, the European Way of Law)' in J.E. Nijman and A. Nollkaemper (eds), New Perspectives on the Divide between National and International Law (Oxford: Oxford University Press, 2007), 118.

7 Slaughter, A New World Order (2004), 119.

${ }^{8}$ C. Kraft-Kasack, 'Transnational Parliamentary Assemblies: A Remedy for the Democratic Deficit of International Governance?' (2008) 31 West European Politics, 534.

9 Kraft-Kasack, 'Transnational Parliamentary Assemblies: A Remedy for the Democratic Deficit of International Governance?' (2008) 31 West European Politics, 552-553.

${ }_{10}$ Kraft-Kasack, 'Transnational Parliamentary Assemblies: A Remedy for the Democratic Deficit of International Governance?’ (2008) 31 West European Politics, 553.

11 R. Cutler, 'International Parliamentary Instutitions as Organizations' (2013) 4 Journal of International Organizations Studies, 104.

12 M. Andrés and S. Stavridis, 'Parliaments and Parliamentarians as International Actors' in B. Reinalda (ed.), The Ashgate Research Companion to Non-State Actors (Farnham: Ashgate, 2011), 101.

12 N. Walker, 'Postnational Constitutionalism and Postnational Public Law: A Tale of Two Neologisms' (2012) 3 Transnational Legal Theory, 114.
} 
multilayered international parliamentarism. Its occurrence is a corollary of the incremental process of the globalisation of parliaments as an institutional response to the globalisation of law and politics in general. Parliaments' functions are moulded by the ever narrower gaps between nations, states and citizens. Increased international contacts among parliaments foster their 'diplomatic' actorship in foreign affairs in a concerted attempt to counterbalance globalisation-propelled intergovernmental and transgovernmental ways of doing politics and making law. This in turn accentuates the deliberative function of parliaments and attenuates globalisation's push towards 'negotiated democracy', whereby governments agree on common rules with other governments without much parliamentary interference. The development of international parliamentarism via mutually interlaced forums helps move parliamentary democracy closer towards 'deliberative negotiation democracy'. ${ }^{13}$ This article therefore subscribes to a systemic approach to deliberative democracy, which posits that no single deliberative forum, including parliaments, is sufficiently capable of legitimising decisions on its own. Instead, the interdependencies and interactions between and among individual sites for the politicisation of policy making ought to be integrated into the analysis because they can make up for the deficiencies of any given site and thus improve the democratic quality of the entire system. ${ }^{14}$

Speaking about the future of global governance, David Kennedy indeed argued that the objective of 'new politics' is to carry the democratic values of individual rights, economic self-sufficiency, citizenship, community empowerment and political participation to the sites of global and transnational authority. ${ }^{15}$ This opening and multiplication of arenas for political contestation, conflict and struggle in search of greater conversation, heterogeneity, interaction and ethical pluralism is precisely where multilayered international parliamentarism makes its greatest contribution. Conducting parliamentary work across layers fertilises the political stratum that conditions the creation, implementation and application of law rather than nurturing parliaments' lawmaking capacity as such.

The diversification of the avenues of parliamentary communication contributes to addressing legislative divergences, interdependencies and externalities by means of argument-based institutional pressure in the form of 'parliamentary lobbying'. International parliamentarism is hence a massive conveyor belt for interest mediation between the centres of democratic gravity, which remain entrenched in domestic political arenas, structured by domestic levers of constitutionalism and arbitrated through domestic public spheres. The

\footnotetext{
13 A. Peters, 'The Globalization of State Constitutions' in J.E. Nijman and A. Nollkaemper (eds), New Perspectives on the Divide between National and International Law (Oxford: Oxford University Press, 2007), 281. 14 J. Mansbridge et al, 'A Systemic Approach to Deliberative Democracy' in J. Parkinson and J. Mansbridge (eds), Deliberative Systems: Deliberative Democracy at the Large Scale (Cambridge: Cambridge University Press, 2012), 2-3.

${ }^{15}$ D. Kennedy, 'The Mystery of Global Governance' in J.L. Dunoff and and J.P. Trachtman (eds), Ruling the World? Constitutionalism, International Law, and Global Governance (Cambridge: Cambridge University Press, 2009), 67.
} 
argument that globalisation and growing interdependence falsify the presumption that national democracy is the most inclusive and deliberative locus of decision making is still a difficult one to make, ${ }^{16}$ because domestic political realms continue to guarantee the highest degree of participation, the greatest possibility for structured deliberation, and the most extensive safeguards for the enforcement of parliamentary rights in the political process. The globalisation of parliaments therefore still has a chiefly domestic effect. International parliamentarism enhances domestic law, politics and governance without putting them in jeopardy. It complements national democracy rather than supplanting it.

The same applies to the European Union. The international activity of the European Parliament (EP) does not thwart EU democracy, but upgrades it by enriching the public debate. In this regard, Bieber's description of the EP's global endeavour confirms the internal rootedness thereof:

The European Parliament's activities in the sphere of general international politics provides the most striking example of a parliament's modern role in this field [...] The Parliament's role as an international forum may amplify the common values of western civilization and hence renders them effective either by influencing governments of Member States and third nations or by directly strengthening them as parameters of the international order. The international effect of Parliament's role as a forum is based on an internal function which only the Parliament can fulfill: the capacity to aggregate the internal support of the European peoples for those basic values. ${ }^{17}$

As the most advanced transnational assembly in the world, the EP has the greatest democratic credentials to lead the parliamentary legitimisation of decision making beyond the state and has so far played a 'crucial role in shaping interparliamentary relations at all levels of regional cooperation'. ${ }^{18}$ This is why this article adopts an EU perspective.

The structure of the article is as follows. First, we conceptualise multilayered international parliamentarism by dissecting its structure and explaining global parliamentary layering. Second, in order to depict the existence and operation of parliamentary interdependence on the international level, we conduct a thorough case study of EU-Brazil relations. We analyse the legal and political bases for bilateral interparliamentary cooperation between them through the lens of formal arrangements as well as through examples from political praxis. To illustrate the multilayered character of interparliamentary liaison, we continue with an

\footnotetext{
16 S. Besson, 'Whose Constitution(s)? International Law, Constitutionalism, and Democracy' in J.L. Dunoff and J.P. Trachtman (eds), Ruling the World? Constitutionalism, International Law, and Global Governance, (Cambridge: Cambridge University Press, 2009), 404.

17 R. Bieber, 'Democratic Control of International Relations of the European Union' in E. Cannizzaro (ed.), The European Union as an Actor in International Relations (The Hague: Kluwer Law International, 2002), 110 (emphasis added).

18 A. Cofelice and S. Stavridis, 'The European Parliament as an International Parliamentary Institution (IPI)' (2014) 19 European Foreign Affairs Review, 165.
} 
examination of the multilateral parliamentary links between these two polities, which evolve within the Euro-Latin American Parliamentary Assembly (EuroLat) as well as through the EP's cooperation with the Mercosur Parliament (Parlasur) and the Latin American Parliament (Parlatino). Third, on this basis we exemplify multilayered international parliamentarism with an in-depth empirical insight into the reaction of Latin American parliaments to the EU's Returns Directive. Finally, conclusions are drawn on the advantages of multilayered international parliamentarism for the democratisation of international politics, since this phenomenon is not restricted to the EP's global actorness but may apply in relation to many other regions of the world, such as Africa, Asia or North America.

\section{THE CONCEPT OF MULTILAYERED INTERNATIONAL PARLIAMENTARISM}

\subsection{The Structure of International Parliamentarism}

Parliamentary engagement in international affairs is chiefly threefold and consists of influencing foreign policy domestically, conducting parliamentary diplomacy and establishing parliamentary bodies of international organisations. ${ }^{19}$ These three activities are closely intertwined because, in the absence of significant decisionmaking power, domestic scrutiny of foreign policy incites parliaments to externalise their work beyond the borders of their polities in order to maximise their effectiveness, increase their impact on executive decisions and, generally, counteract the 'hollowing out of domestic democracy'. ${ }^{20}$ By the same token, parliamentary diplomacy is the key substantive component and a conditio sine qua non of the parliamentarisation of international organisations. This last type of parliamentary engagement is the most advanced manifestation of what Neil Walker has labeled 'transnational parliamentarianism'. ${ }^{21}$ There is, nevertheless, a whole spectrum of appellations for this phenomenon. The most common one is international parliamentary institutions (IPIs), which Cutler defines as international institutional forums for multilateral deliberations in which at least three states or transgovernmental units are represented by parliamentarians. ${ }^{22}$ They can be further classified into international parliamentary organs (IPOs) and international

\footnotetext{
19 Malamud and Stavridis, 'Parliaments and Parliamentarians as International Actors' in The Ashgate Research Companion to Non-State Actors (2011), 101.

${ }^{20}$ Peters, 'The Globalization of State Constitutions' in New Perspectives on the Divide between National and International Law (2007), 284.

${ }^{21}$ Walker, 'Postnational Constitutionalism and Postnational Public Law: A Tale of Two Neologisms' (2012) 3 Transnational Legal Theory, 80.

22 Cutler, 'International Parliamentary Institutions as Organizations' (2013) 4 Journal of International Organizations Studies, 106.
} 
parliamentary associations (IPAs), ${ }^{23}$ which differ insofar as the former belong to intergovernmental organisations while the latter are independent, self-constituted groups of parliamentarians. One may also speak of international or transnational parliamentary assemblies.

Yet, whichever phrase one uses to define international parliamentary action, each of them as a rule refers to multilateral parliamentary cooperation. The shortcoming of the existing literature is that it places excessive focus on IPIs and treats them as singular manifestations of international parliamentarism. This skews the portrayal of the political reality, which is denser than the current approaches suggest. This article submits, first, that bilateral forums are also important frameworks for international parliamentarism and, second, that there are a plethora of intricate interactions across and between these multilateral and bilateral forums. On the one hand, while multilateral cooperation may be the most visible form of international parliamentarism, national parliamentarians (MPs, senators and peers), regional parliamentarians (members of regional integration parliaments) and supranational ones (members of the EP or MEPs) engage in bilateral relations of an international character too. ${ }^{24} \mathrm{~A}$ notable example of it is the Transatlantic Legislators' Dialogue between the EP and the US Congress. ${ }^{25}$ As this article shows, a similar arrangement has been instituted between the EP and the Brazilian National Congress (Congresso Nacional do Brasi). On the other hand, there are also bilateral relations between IPIs themselves, such as those between the EP and Parlasur. All of these frameworks are institutionalised forms of parliamentarism which merit a separate place on the global parliamentary map. ${ }^{26}$

\subsection{The LaYering of International Parliamentarism}

As a result of the proliferation of international parliamentary bodies, the layers of interparliamentary cooperation have become more diverse. Typically, the engagement of any given parliament in any given region is exhausted by its participation in one international interparliamentary body established for that purpose. This mostly takes the form of an IPI. For example, in the Mediterranean region, the EP is represented in the Euro-Mediterranean Parliamentary Assembly, as the parliamentary component of the Euro-Mediterranean Partnership. ${ }^{27}$ In the

\footnotetext{
23 Šabic, 'Building Democratic and Responsible Global Governance: The Role of International Parliamentary Institutions' (2008) 61 Parliamentary Affairs, 258.

${ }^{24}$ C. Quispe, 'La Cooperación Interparlamentaria en América Latina' (2012) 2 Revista Andina de Estudios Políticos, 71.

25 D. Jancic, 'The European Parliament and EU-US Relations: Revamping Institutional Cooperation' in E. Fahey and D. Curtin (eds), A Transatlantic Community of Law: Legal Perspectives on the Relationship between the EU and US Legal Orders (Cambridge: Cambridge University Press, forthcoming in 2014).

26 In broad functional terms, one may also conceive of international parliamentarism in the context of 'transnational advocacy networks' inasmuch as international parliamentary bodies frequently resort to advocacy techniques to achieve their goals. See M.E. Keck and K. Sikkink, Activists beyond Borders: Advocacy Networks in International Politics (Ithaca: Cornell University Press, 1998), 9.

27 See R. Pace and S. Stelios. 'The Euro-Mediterranean Parliamentary Assembly, 2004-2008: Assessing the First Years of the Parliamentary Dimension of the Barcelona Process' (2010) 21 Mediterranean Quarterly, 90-113.
} 
case of the region located at the EU's eastern gates comprising certain post-Soviet states, the EP forms part of the Euronest Parliamentary Assembly, as the parliamentary element of the Eastern Partnership. ${ }^{28}$

However, this paradigm of 'unidimensional' international parliamentarism has become inaccurate and the region of South America furnishes an excellent example. For instance, the EP meets with Chilean and Mexican parliamentarians both bilaterally within the respective EU-Chile and EU-Mexico Joint Parliamentary Committees and multilaterally within EuroLat and Parlatino. In the case of Brazil, interparliamentary cooperation evolves not only in the form of bilateral relations between the EP and the Brazilian Congress but also multilaterally through EuroLat, Parlasur and Parlatino. Common to these instances is the concurrent representation of the same parliamentary body in multiple international parliamentary forums devoted to the same region.

The international activity of parliaments is therefore multifarious and, due to the transnational nature of contemporary policy making, it is likely to develop not only in the format of isolated parliamentary frameworks but in that of interconnected webs of parliaments. They may intersect within various international forums, whether bilateral or multilateral, formal or informal, more or less structured, and more or less empowered to issue pronouncements. This interconnectedness between the same parliamentary institutions across forums, regions and levels of governance casts the global role of parliaments as less fragmented than it prima facie appears. Consequently, more frequent contact between the same parliamentary institutions on different topics carries concrete mutual benefits. These include a greater potential for continuous debate and consultation on contentious matters and the maintenance of a firmer liaison between parliamentarians and their staff. This may help improve their understanding of the common challenges and threats facing their polities and catalyse the search for optimal policy solutions. In turn, this increases the likelihood of polities respecting each other's legislation and implementing mutual agreements. Multilayered international collaboration between parliaments can therefore boost their say in global and domestic politics and corroborate their classic constitutional functions of legislating and ensuring executive accountability. International parliamentarism, furthermore, is multilayered not only borizontally, i.e. between two or more same parliaments, but also vertically, i.e. in a variety of formats. These formats may range from inter-delegation meetings, formalised personal committee-to-committee meetings, informal visits and videoconferences. With these elements in mind, I define multilayered international parliamentarism as the international activity that develops between the same parliamentary bodies in two or more interparliamentary forums in the same period regarding the same

\footnotetext{
28 See H. Kostanyan and B. Vandecasteele, 'The EuroNest Parliamentary Assembly: The European Parliament as a Socializer of Its Counterparts in the EU's Eastern Neighbourhood?' (2013) 5 College of Europe, EU Diplomacy Papers.
} 
region. In the remaining sections, I operationalise this concept with the example of EU-Brazil relations.

\section{THE EUROPEAN PARLIAMENT AND THE BRAZILIAN CONGRESS: AN EVOLVING PARTNERSHIP?}

\subsection{BILATERAL EU-BRAZIL INTERPARLIAMENTARY RELATIONS}

\section{A. Legal Framework}

The importance of democracy in EU-Brazil relations are visible from the 1992 Framework Cooperation Agreement, ${ }^{29}$ whose first Article states that their cooperation is based on the respect for the democratic principles and human rights. While regulating collaboration in the fields such as trade, ${ }^{30}$ investment, finance, industry and technology, the Agreement also acknowledges the value of mutual consultation on 'international issues of mutual interest'. ${ }^{31}$ However, the Agreement does not mention interparliamentary relations as such.

In the EU, the Agreement is operationalised through Brazil Country Strategy Papers, which the European Commission (Commission) publishes in order to provide guidance for the implementation of the collaborative arrangements agreed. There have so far been two such Papers, one for 2001-2006 and the other for 2007-2013. The latter states that the key objectives of enhancing bilateral relations are to improve the sectoral dialogues between the EU and Brazil as well as to expand cooperation, exchanges and mutual awareness between relevant institutions. ${ }^{32}$ While not explicitly stated, this encompasses interparliamentary collaboration. The Commission furthermore seeks to widen the interregional political dialogue and facilitate the development of EU-Mercosur relations. ${ }^{33}$

The key forums for bilateral EU-Brazil relations are summits, which are intergovernmental gatherings of European and Brazilian leaders at the highest political level. The first such summit took place in Lisbon in July 2007 and officially established a strategic partnership between the EU and Brazil in order to address bilateral and multilateral challenges. ${ }^{34}$ The second summit, which was held

\footnotetext{
${ }^{29}$ Framework Agreement for Cooperation between the European Economic Community and the Federative Republic of Brazil of 29 June 1992 [1995] OJ L262/54.

30 See more on this in: R. Leal-Arcas, 'The European Union and New Leading Powers: Towards Partnership in Strategic Trade Policy Areas' (2009) 32 Fordham International Law Journal, 382-386.

31 Art. 2 thereof.

32 European Commission, Brazil Country Strategy Paper 2007-2013 [2007] E/2007/889, 26.

33 European Commission, Communication to the European Parliament and the Council 'Towards an EU-Brazil Strategic Partnership', COM (2007) 281, 15.

34 See accounts in: R.G. Whitman and A.P. Rodt, 'EU-Brazil Relations: A Strategic Partnership?' (2012) 17 European Foreign Affairs Review, 27-44; E.M. Ceia, 'The New Approach of the European Union towards the Mercosur and the Strategic Partnership with Brazil' (2008) 61 Studia Diplomatica, 81-96; M. Emerson and R. Flôres, Enhancing the Brazil-EU Strategic Partnership: From the Bilateral and Regional to the Global (Brussels and Rio de Janeiro: CEPS and FGV, 2013); B. Znojek, 'The European Union and Brazil as
} 
in Rio de Janeiro in December 2008, was of paramount importance for bilateral parliamentarism. The then adopted Joint Action Plan laid down a fivefold scheme to construct the Euro-Brazilian strategic partnership and one of them is through people-to-people contacts. Within this category, the Action Plan promotes twofold interparliamentary interaction: (a) by initiating a regular structured dialogue between MEPs and Brazilian Congressmen; and (b) by direct intercommittee contacts on all subjects on common interest. ${ }^{35}$ At the moment, there exist some 30 sectoral dialogues between the EU and Brazil, which are aimed at exchanging know-how in various areas. ${ }^{36}$ One of them is the dialogue between the EP and the Brazilian Congress. The fourth summit, held in Brasilia in July 2010, acknowledged that bilateral interparliamentary cooperation has commenced in the form of informal visits, for example the visit of the EP's Committee on International Trade and its Delegation for relations with the Mercosur countries. ${ }^{37}$ The fifth summit, organised in Brussels in October 2011, brought new impetus. It recognised that 'parliaments are a fundamental expression of democratic values and of people's representation in the democratic processes' and concluded that visits and exchanges between the EP and the Brazilian Congress had been increasing and solidifying since the onset of the strategic partnership. Both sides expressed commitment to a further strengthening of the interparliamentary dialogue..$^{38}$ This dialogue is supported by the MEPs, who in 2009 called upon EU institutions and the Brazilian Government to provide them with 'regular and detailed information on the state of play of the strategic partnership'. 39

\section{B. Internal Parliamentary Organisation}

While the EP currently possesses no internal body specifically for EU-Brazil relations, in a 2012 resolution MEPs stated that the creation of a delegation for relations with Brazil could be considered. ${ }^{40}$ On the same occasion, they advised that EU Delegations in BRICS countries (Brazil, Russia, India, China and South Africa) should include EP liaison officers so as to: (a) foster a greater understanding of the national parliamentary dimension in each of those countries; (b) promote closer bilateral cooperation and dialogue between the EP and their national parliaments; and (c) promote democratic accountability of the decisionmaking processes in the G-8 and the G-20. These initiatives signify that, although Mercosur has been the main framework of EU-Brazil cooperation, there has been

Privileged Partners? Difficult Path to an Authentic Strategic Partnership' (2012) 24 Polish Institute for International Affairs Policy Paper, 1-8.

$352^{\text {nd }}$ EU-Brazil Summit, 'Brazil-EU Strategic Partnership-Joint Action Plan', Rio de Janeiro, 22 December 2008, 39.

${ }^{36}$ See http://sectordialogues.org/en/pagina-estatica/project/presentation [Accessed 27 March 2014].

$374^{\text {th }}$ EU-Brazil Summit, 'Joint Statement', Brasília, 14 July 2010, point 25, 11.

$385^{\text {th }}$ EU-Brazil Summit, 'Joint Statement', Brussels, 4 October 2011, 27-28.

39 Recommendation of the European Parliament to the Council of 12 March 2009 on the European Union-Brazil Strategic Partnership [2010] OJ C87E/168, point 1(z)(ad)-(ae).

40 Resolution of the European Parliament on the EU foreign policy towards the BRICS and other emerging powers: objectives and strategies [2013] OJ C239E/1, point 28. 
a shift in priorities whereby Brazil is viewed as 'a power in its own right' and as 'an increasingly important partner for Europe in dealing with all of the major policy challenges that will need to be addressed in the twenty-first century'.41

On the other side of the Atlantic, the Brazilian Chamber of Deputies (Câmara dos Deputados) created in June 2008 a bicameral parliamentary group for relations with the EU.42 It is composed of 78 MPs and 22 senators. As a member of this group mentioned, "parliamentary diplomacy is as important as official diplomacy. For that reason, this parliamentary group will interact with the EP in various matters, such as immigration, business, customs barriers, sanitary barriers and education projects'. ${ }^{43}$ In addition, the Brazilian Foreign Affairs Ministry has a Department for Europe ${ }^{44}$ whose work is appraised by Congress.

\section{Mutual Parliamentary Awareness and Pronouncement}

The following empirical examples illustrate manifold regulatory interdependence between the EU and Brazil. It is shown that their legislatures pay heed to the interregional dimension of policy making and that they keep a watchful eye over each other's decision-making processes. ${ }^{45}$

The EP occasionally comments on Brazilian legislative initiatives that are of global or interregional importance, gives its views thereon, and offers recommendations. For instance, some nine months in advance of the UN Conference on Sustainable Development, which took place in Rio de Janeiro in June 2012 to address global economic and environmental challenges, the EP passed a resolution in which concern was expressed about the Forest Code that the Brazilian Senate was due to adopt. The reason for this alert was that the Code would 'exacerbate deforestation in the Brazilian Amazon, thus hindering international climate change mitigation efforts'. MEPs urged Brazil to 'make a clear commitment to protect the Amazon forest and stem criminal harassment of representatives of civil society pursuing environmental protection'. ${ }^{46}$ On another occasion, the EP invited developing countries to follow the example of Brazil's successful Bolsa Familia (Family Grant) programme and devise similar social protection schemes to shield the most vulnerable members of their societies. ${ }^{47}$ When it comes to food policy, the MEPs raised objections regarding, on the one

${ }^{41}$ R. Roett, The New Brazil (Washington DC: Brookings Institution Press, 2010), 141-142.

${ }^{42}$ Resoluscão da Câmara dos Deputados no. 3/08 que cria o grupo parlamentar Brasil-União Européia, Diário da Câmara dos Deputados of 6 June 2008, 25589.

${ }^{43}$ César Halum MP, see http://t1noticias.com.br/antigas/noticias/halum-sera-empossado-nesta-quartano-grupo-parlamentar-brasil-uniao-europeia-na-cni-em-brasilia/23581/\#.UzRRLY-NwSw [Accessed 27 March 2014].

44 See www.itamaraty.gov.br/o-ministerio/conheca-o-ministerio/organograma/subsecretaria-geralpolitica-i/deu-departamento-da-europa [Accessed 27 March 2014].

${ }^{45}$ See on EU-Brazilian interdependence in many areas: A. Valladão, 'L'UE et le Brésil: Un Partenariat Naturel' in G. Grevi and Á. de Vasconcelos (eds), Chaillot Paper No. 109 Partnerships for Effective Multilateralism: EU Relations with Brazil, China, India and Russia' (EUISS: Paris, 2008), 34 et seq.

46 Resolution of European Parliament on developing a common EU position ahead of the United Nations Conference on Sustainable Development (Rio+20) [2011] OJ C22E/114, points 60 and 61.

${ }^{47}$ Resolution of the European Parliament on the impact of the financial and economic crisis on human rights [2013] OJ C242E/260, point 25. 
hand, reports by the Brazilian National Health Surveillance Agency on the widespread use of pesticides that are banned in the EU and that as such carry grave health risks and, on the other hand, reports by the EU Food and Veterinary Office on the 'failure of Brazilian beef to meet EU producer and consumer standards' ${ }^{48}$ In the same policy field, the EP was also mindful of the repercussions of EU policies for Brazil. To wit, the MEPs prompted the Commission to assess the impact of the reform of the EU's common organisation of the sugar market for Brazil's policies on sugar production and processing. The objective was to deter Brazil's 'unsustainable latifundary method of sugar production', which is dominated by a small number of individuals to the detriment of the many workers in sugar fields and factories. ${ }^{49}$ In yet other pronouncements, the EP emphasised the relevance of Brazilian policies for the EU. For example, in order to improve EU competitiveness and remove barriers to global trade, MEPs adopted a resolution requesting the Commission, when framing EU policies, to carry out systematic evaluations of similar policies by the EU's major partners, among which Brazil. ${ }^{50}$ EU-Brazil parliamentary cooperation has also been promoted in the context of Internet regulation. Namely, the EP underlined the importance of raising the parliamentary profile of the Internet Governance Forum and expressed eagerness to cooperate with the Brazilian, Indian and other interested assemblies on these matters. ${ }^{51}$

For its part, the Brazilian Congress maintains regular cognizance of EU affairs in a variety of formats, including hearings with MEPs and public expert debates. For instance, in October 2013, Congress hosted a working group of the EP's Delegation for relations with Mercosur in order to discuss the association agreement with Mercosur and the development of the EU-Brazil partnership. Transpiring from the Delegation's meetings with representatives of the external affairs committees of both Houses of Congress, was the EU's awareness of the politico-economic importance of Brazil and its leadership within Mercosur. ${ }^{52}$ The same month, the Chamber of Deputies' Committee for External Relations and National Defence held a hearing with Daniel Cohn-Bendit MEP on climate change and environment protection. ${ }^{33}$ Furthermore, in March 2014 the Chamber

\footnotetext{
48 Resolution of the European Parliament on EU agriculture and international trade [2011] OJ C199E/48, points 52 and 53 .

${ }^{49}$ Resolution of the European Parliament on the forthcoming reform of the common organisation of the market in sugar [2005] OJ C320E/271, point 30.

${ }^{50}$ Resolution of the European Parliament on the Single Market review: tackling barriers and inefficiencies through better implementation and enforcement [2007] OJ C187E/80, point 43.

51 Resolution of the European Parliament on the second Internet Governance Forum held in Rio de Janeiro from 12-15 November 2007 [2008] OJ C61E/252, point 4.

52 See

http://eeas.europa.eu/delegations/brazil/press corner/all news/news/2013/20131101 01 pt.htm [Accessed 28 March 2014].

53 Requerimento no. 315/2013 (Alfredo Sirkis MP) of 16 July 2013, see www.camara.gov.br/proposicoesWeb/fichadetramitacao?idProposicao $=585557$ [Accessed 27 March 2014].
} 
hosted a visit by an EP delegation, whose aim was to discuss the internal functioning of the two parliaments, such as the legislative process, voting and the structure and operation of committees and parliamentary groups. The meeting resulted in the conclusion of a Memorandum of Understanding on the International Technical Cooperation, which was also signed by the Brazilian Senate (Senado). The goal of this Memorandum is to continue to share parliamentary information, practices and working methods as well as to increase mutual learning through exchange programmes for administrative staff. ${ }^{54}$ The Senate also organises expert hearings on EU topics. For example, the impact of the Eurozone crisis on EU-Brazil commercial relations and on the Brazilian economy was publically discussed in the Committee for External Relations and National Defence in September 2011 and March 2012.55 This is precisely the period surrounding the EU's adoption of the so-called Six Pack of measures intended to reform Stability and Growth Pact. It has indeed been argued that, while the EU remains an attractive commercial partner to Brazil, the sovereign debt crisis has severely challenged the appeal of the EU model for regional integration in Latin America. ${ }^{56}$ Another example is the examination by Brazilian senators of the EU's Water Framework Directive. ${ }^{57}$ Due to the similarities between the EU's and Brazil's difficulties in implementing policies in the very diverse regions existing within their territories, in May 2009 the Senate's Committee for Environment, Consumer Protection and Supervision and Control conducted a comparison between EU legislation and the National Water Resources Policy enacted by the Brazilian Water Act. 58 The Committee Chairman, Renato Casagrande, suggested that EU policy could be used as a model for regulating transnational water paths within Mercosur. ${ }^{59}$

These examples document the wealth of advocacy practices of the EU and Brazilian parliaments in numerous policy fields. Their importance lies in the mutual awareness of the respective regulatory and decision-making processes. These are crucial ingredients of multilayered international parliamentarism because the search for policy rapprochement may spill over to mutual multilateral forums, as outlined below.

\subsection{MULTILATERAL EU-BRAZIL INTERPARLIAMENTARY RELATIONS}

The lynchpin of multilayered international parliamentarism is the fact that representatives of two same parliamentary bodies meet in different international

\footnotetext{
54 See http://www12.senado.gov.br/noticias/materias/2014/03/21/diretores-firmam-acordopermanente-de-cooperacao-entre-parlamentos-brasileiro-e-europeu [Accessed 28 March 2014].

55 See www.senado.gov.br/atividade/comissoes/CRE/audPub.asp [Accessed 27 March 2014].

56 E. Lazarou, 'A Paradigm in Trouble? The Effects of the Euro Crisis on the European Model for Regional Integration in South America' in L. Fioramonti (ed.), Regions and Crises: New Challenges for Contemporary Regionalisms (Basingstoke: Palgrave Macmillan, 2012), 195.

57 Directive 2000/60/EC establishing a framework for Community action in the field of water policy [2000] OJ L327/1.

58 Lei no. 9.433 of 8 January 1997.

${ }^{59}$ Jornal do Senado, Ano XV, No. 3.024 of 22 May 2009, 6.
} 
parliamentary forums devoted to the same region. In the case of the EU and Brazil, this unravels within three frameworks: EuroLat, Mercosur and Parlatino. I examine them in turn below.

\section{A. Cooperation within the Euro-Latin American Parliamentary Assembly (EuroLat)}

The creation of EuroLat was strongly advocated by the EP. In November 2001, MEPs adopted a resolution recognising that EU-Latin American parliamentary dialogue has a role in 'lending legitimacy to the different integration processes under way in both regions' and that it should be modernised by setting up an EULatin American Transatlantic Assembly. ${ }^{60}$ In April 2006, the EP reiterated the need for such an Assembly, while undertaking to strengthen biregional parliamentary diplomacy through the network of standing and ad hoc parliamentary delegations to interparliamentary forums and by requiring the inclusion of EP liaison officers in the main Commission delegations in the region. ${ }^{61}$

On 8 November 2006, EuroLat was established in Brussels as a parliamentary dimension of the Biregional Strategic Partnership between the EU, Latin America and the Caribbean (EU-LAC). ${ }^{62}$ This multilateral parliamentary body succeeded the EU-Latin American Interparliamentary Conference, which had convened biennially since 1974. EuroLat gathers 150 parliamentarians: 75 MEPs and 75 delegates from the Latin American component, which consists of Parlatino, Parlasur, the Andean Parliament, the Central American Parliament and the Joint Parliamentary Committees with Mexico and Chile. EuroLat has an Executive Secretariat, a Governing Board, a Plenary Assembly and three standing committees. ${ }^{63}$ The Council of the EU and the Commission may actively participate in EuroLat's work.

According to the Constituent Act, the role of EuroLat is to 'debate, control and review' all questions relating to the Partnership. ${ }^{64}$ These questions cover a broad range of matters including democracy, external policy, governance, integration, peace, human rights, education, environment, culture as well as economic, financial, commercial and social affairs. ${ }^{65}$ In these policy areas EuroLat may adopt resolutions, recommendations, opinions, messages and statements for the attention of EU-LAC summits and ministerial groups and conferences

\footnotetext{
${ }^{60}$ Resolution of the European Parliament on a global partnership and a common strategy for relations between the European Union and Latin America [2002] OJ C140E/569, recital H, points 5(1) and 9.

61 Resolution of the European Parliament on a stronger partnership between the European Union and Latin America [2006] OJ C296E/123, points 8(a), 16 and 42.

62 M.C. González, 'Eurolat: Une Assemblée Parlementaire Euro-Latino-Américaine' (2008) 515 Revue du Marché Commun et de l'Union Européenne, 94-95. See also a description of its basic features in: S. Stavridis et al, 'The Origins, Structures and Functions of the Euro-Mediterranean and Euro-Latin American Interparliamentary Assemblies' in O. Costa et al. (eds), Parliamentary Dimensions of Regionalization and Globalization: The Role of Inter-Parliamentary Institutions (Basingstoke: Palgrave Macmillan, 2013), 221-226.

63 Art.4 EuroLat Constituent Act.

64 Art.5(a) EuroLat Constituent Act.

65 Art.2 EuroLat Constituent Act.
} 
devoted to the development of the Partnership. ${ }^{66}$ EuroLat members may also put questions for oral or written answer to the ministerial bodies of the Latin American regional integration organisations, the Presidency-in-Office of the EULAC Summit, the Council of the EU and the Commission. ${ }^{67}$ Written questions and answers are published by the EU in its Official Journal and by the participating regional integration parliaments. Oral questions are held each session upon decision to this effect by the Executive Bureau and they last up to two hours. The said executive bodies are then invited to give brief answers and a debate may follow if requested by twenty or more EuroLat members.

Given its composition, breadth of scope and the existence of committees that ensure the completion of preparatory works in between the yearly conventions of the Plenary Assembly,68 EuroLat provides a forum for ongoing deliberation between MEPs and Brazilian parliamentarians, who may be part of Parlatino and Parlasur delegations. As proposed by two commentators, an early warning system, inspired by that applied in the European Union between national parliaments and EU institutions, ${ }^{69}$ could be installed within EuroLat to remedy the lack of coordination between legislative initiatives of biregional interest and to avoid the duplication of work where approaches converge. ${ }^{70}$ Besides this potential for policy collaboration, it has been argued that EuroLat is the most adequate forum for maintaining a community of values between the European and Latin American regions..$^{71}$

\section{B. Cooperation between the EP and the Mercosur Parliament (Parlasur)}

Mercosur (Mercado Comun del Sur or the Common Market of the Southern Cone) was established by the Treaty of Asuncion in 1991. While this regional organisation was founded by Argentina, Brazil, Paraguay and Uruguay, Paraguay was suspended in June 2012, Venezuela became a full member in July 2012, and Bolivia has been en route to membership since December 2012. Democracy lay at the root of Mercosur and there is 'huge and incontrovertible evidence that all the key players perceived $[. .$.$] democracy as an important factor for integration in the$

\footnotetext{
66 Art.5(c)-(d) EuroLat Constituent Act in conjunction with arts 16-18 EuroLat Rules of Procedure of 8 November 2006, as amended in 2007, 2009 and 2013.

67 Arts 20-21 EuroLat Rules of Procedure.

${ }^{68}$ Art.7 EuroLat Constituent Act.

${ }^{69}$ See I. Cooper, 'A "Virtual Third Chamber" for the European Union? National Parliaments after the Treaty of Lisbon' (2012) 35 West European Politics 441-465; D Jancic, 'Representative Democracy across Levels? National Parliaments and EU Constitutionalism' (2012) 8 Croatian Yearbook of European Law and Policy, 227-265; P. Kiiver, The Early Warning System for the Principle of Subsidiarity: Constitutional Theory and Empirical Reality (London: Routledge, 2012).

70 J.J.F. Alles and M.T.F. Alles, 'La Cooperación Interparlamentaria Union Europea-Iberoamérica: Una Estrategia entre el Marketing Político y la Integración Birregional' in Europa-América Latina. Dos Caminos, ¿Un Destino Común? (Santiago de Chile: RIL Editores, 2012), 62.

${ }^{71}$ I. Vittini, 'La Asamblea Euro-Latinoamericana EuroLat. Antecendentes y su Importancia para la Promoción de la Comunidad de Valores' in Europa-América Latina. Dos Caminos, ¿Un Destino Común? (Santiago de Chile: RIL Editores, 2012), 37.
} 
Southern Cone'. ${ }^{72}$ Apart from the Common Market Council, Common Market Group, Trade Commission, Economic-Social Consultative Forum and Administrative Secretariat, Mercosur has its own Parliament. ${ }^{73}$ Envisaged originally as the Joint Parliamentary Committee, ${ }^{74}$ the 1994 Ouro Preto Protocol specified that it was to be appointed by the participating national parliaments and entrusted with the speeding up of domestic implementation of Mercosur decisions. ${ }^{75}$ In December 2005, a Constitutive Protocol replaced the Joint Parliamentary Committee with a directly elected Mercosur Parliament. ${ }^{76}$ While laying down its organisation and competence, which does not include legislation, ${ }^{77}$ the Protocol charges Parlasur with 'maintaining institutional relations with parliaments of third countries and other legislative institutions', which encompasses the EP. ${ }^{78}$

EU-Mercosur relations were established in 1995 by means of an Interregional Framework Cooperation Agreement, which entered into force in 1999.79 This Agreement strengthens the existing relations between the two regions and sets the ground for an interregional association. ${ }^{80}$ Cooperation is to be developed in many diverse fields, including economy, trade, intellectual property, energy, transport, technology and environment. To this end, a political dialogue on bilateral and multilateral issues is instituted at the level of the respective executive branches (Heads of State, ministers and senior officials). ${ }^{81}$ However, although the Agreement makes no mention of interparliamentary cooperation, it does encourage 'closer relations between the Parties and their respective institutions', ${ }^{82}$ particularly by fostering regular exchanges of information, advice and know-how. ${ }^{83}$ The Joint Declaration on Political Dialogue promotes 'contacts, information exchanges, and consultation, especially meetings at the appropriate level between

\footnotetext{
${ }^{72}$ G.L. Gardini, The Origins of Mercosur: Democracy and Regionalization in South America (New York: Palgrave Macmillan, 2010), 151.

${ }^{73}$ Art.1 Ouro Preto Protocol of 16 December 1994.

74 Art.24 thereof.

75 Arts 22-25 Ouro Preto Protocol.

76 Art.6 Constitutive Protocol of the Mercosur Parliament of 9 December 2005.

77 The powers and achievements of Parlasur have so far been rather limited. A. Malamud and C. Dri, 'Spillover Effects and Supranational Parliaments: The Case of Mercosur' (2013) 19 Journal of Iberian and Latin American Research, 235.

78 Art.4(16) Constitutive Protocol of the Mercosur Parliament.

${ }^{79}$ Interregional Framework Cooperation Agreement between the European Community and its Member States, of the one part, and the Southern Common Market and its Party States, of the other part [1996] OJ L69/4. See further: G. Müller-Brandeck-Bocquet, 'Perspectives for a New Regionalism: Relations between the EU and the Mercosur' (2000) 5 European Foreign Affairs Review, 561-579; P. Bessa-Rodrigues, 'European Union-Mercosul: In Search of a "New” Relationship?' (1999) 4 European Foreign Affairs Review, 81-98; S. Page, 'The Relationship between the European Union and Mercosur' (1999) 34 International Spectator, 91-108; S. Santander, 'The European Partnership with Mercosur: A Relationship Based on Strategic and Neo-Liberal Principles' (2005) 27 Journal of European Integration, 285-306.

80 Art.2(1) thereof. Negotiations on an Association Agreement began in 2000 and, after their suspension in 2004, they were continued in 2010 and are currently ongoing. See a practitioner's view on this: A. Klom, 'Mercosur and Brazil: A European Perspective' (2003) 79 International Affairs, 351-368.

81 Art.3 Interregional Framework Cooperation Agreement.

82 Art.2(2) thereof (emphasis added).

83 Art.19 thereof.
} 
the various Mercosur and European Union bodies', albeit that the provisions that follow specify collaborative action of an executive nature. ${ }^{84}$ These references nevertheless facilitate cooperation between the EU and Mercosur parliaments. Indeed, Mercosur's Joint Parliamentary Committee has periodically met with the EP since 1996. Until May 2008, there were 13 interparliamentary meetings between the EU and Mercosur. 85

In its Regional Strategy Paper for Mercosur for 2007-2013, the Commission assessed that Mercosur's democracy and transparency deficiencies will 'only partly be addressed' by Parlasur. ${ }^{86}$ Therefore, the EU's first priority is the institutionalisation of Mercosur and the support for Parlasur's development. ${ }^{87}$ The general objective is to democratise Mercosur decisions and optimise the political relations between the EU and Mercosur. The more concrete objectives are: (a) to improve the domestic transposition of Mercosur acts; (b) to reinforce the link between Mercosur decision making and the citizens in order to increase democratic legitimacy and public participation; (c) to transfer know-how relating to Parlasur's administration, communication and management and to the functioning of political groups; and (d) to aid preparations for Parlasur direct elections. The results sought include improved citizen access to Mercosur institutions, better internal organisation of Parlasur, greater transparency and accountability of Mercosur institutions, and smoother coordination between Parlasur and national parliaments. The EU's financial support for Parlasur amounted to some 900.000 euros in the period 2002-2006.88

Finally, the second EU-Brazil summit agreed to 'foster collaboration' between Parlasur and the EP. ${ }^{89}$ Apart from the committees for foreign affairs (AFET), development (DEVE) and international trade (INTA), the main body within the EP that deals with Mercosur is the Delegation for relations with the Mercosur countries. This Delegation originates in the Delegation for relations with South America, which was renamed Delegation for South America and Mercosur in 1996 and assumed its current name in 2004. From June 1991 to April 2008, the EP visited Brazilian officials on seven occasions within the arrangements for cooperation with Parlasur: five times by this Delegation (June 1991, March 1992, September 1995, June 2000 and June 2003), once by the EP Presidency (May 1993) and once by a group of MEPs (November 2003). ${ }^{90}$ These visits were inspired by MEPs' wishes to participate in interregional negotiations on economic

\footnotetext{
${ }^{84}$ Emphasis added.

85 C. Dri, 'Limits of the Institutional Mimesis of the European Union: The Case of the Mercosur Parliament' (2010) 1 Latin American Policy, 63.

${ }^{86}$ European Commission, Mercosur Regional Strategy Paper 2007-2013 [2007] E/2007/1640, 17.

${ }^{87}$ European Commission, Mercosur Regional Strategy Paper 2007-2013 [2007] E/2007/1640, 29.

${ }^{88}$ European Commission, Mercosur Regional Strategy Paper 2007-2013 [2007] E/2007/1640, 63.

$892^{\text {nd }}$ EU-Brazil Summit, 'Brazil-European Union Strategic Partnership-Joint Action Plan', Rio de Janeiro, 22 December 2008, 14.

${ }^{90}$ Dri, 'Limits of the Institutional Mimesis of the European Union: The Case of the Mercosur Parliament' (2010) 1 Latin American Policy, 62.
} 
agreements and to fortify their own legitimacy by stimulating the creation of a new regional parliament. ${ }^{91}$

This overview demonstrates that the relations between the EP and Parlasur aim to have the former assist the latter in strengthening its capacities rather than to spark legislative discussions. It has indeed been empirically shown that the EP was a role model for the establishment and empowerment of Parlasur.92 From the perspective of multilayered international parliamentarism, all of these activities benefit EU-Brazil relations. Within the auspices of EP-Parlasur collaboration, MEPs and Brazilian parliamentarians have ample opportunities for information exchange and institutional learning.

\section{Cooperation between the EP and the Latin American Parliament (Parlatino)}

Established on 10 December 1964 in Lima, Parlatino is an independent, permanent, regional parliamentary organisation composed of 23 parliaments of South American and Caribbean states. ${ }^{93}$ Its structure was only finalised in 1987, when the Institutionalisation Treaty was agreed. Next to a Board of Directors and a General Secretariat, Parlatino is composed of an Assembly and 13 permanent committees. The Assembly is the supreme body of the organisation and gathers 12-member national parliamentary delegations once a year in Parlatino's seat in Panama City. ${ }^{94}$

Parlatino possesses no decision-making authority other than to issue nonbinding declarations and recommendations, for which reason it has been described as a 'symbolic rather than an operative body [that] lacks both political significance and social roots'. ${ }^{55}$ Nevertheless, Parlatino is a vivid example of a forum for

\footnotetext{
${ }^{91}$ Dri, 'Limits of the Institutional Mimesis of the European Union: The Case of the Mercosur Parliament' (2010) 1 Latin American Policy, 63.

92 C. Dri, 'Building the Mercosur Parliament: Integration on European Patterns?' in J. Schoettli (ed.), Democracy, Governance and Citizenship: A Comparative Perspective of Conceptual Flow-Heidelberg Papers in South Asian and Comparative Politics, Working Paper No. 59 (Heildelberg: Uinversity of Heidelberg, 2011), p.162; Dri, 'Limits of the Institutional Mimesis of the European Union: The Case of the Mercosur Parliament' (2010) 1 Latin American Policy, 64 and 70. See more broadly: S. de Camargo, 'União Europeia-Uma Referência Indispensável para o Mercosul' (1999) 21 Contexto Internacional, 83-122. See also D. Ventura, As Assimetrias entre o Mercosul e a União Europeia: Os Desafios de uma Associação Interregional (Barueri: Manole, 2003); M. Mukhametdinov, 'Mercosur and the European Union: Variation among the Factors of Regional Cohesion' (2007) 42 Cooperation and Conflict, 207-228; T. Lenz, 'Spurred Emulation: the EU and Regional Integration in Mercosur and SADC' (2012) 35 West European Politics, 155-173.

${ }^{93}$ See a brief overview in: N. Rausseo, 'El Rol del Parlamento Latinoamericano en el Fortalecimiento de las Instituciones de la Integración', Paper prepared for VII Congreso Internacional del CLAD sobre la Reforma del Estado y de la Administración Pública, Lisbon, 8-11 October 2002, http://unpan1.un.org/intradoc/groups/public/documents/CLAD/clad0044402.pdf [Accessed 13 September 2013].

94 Arts 12-14 Parlatino Statute of 2 August 1991, as amended in 1995, 1997, 2000, 2004, 2006 and 2007.

95 A. Malamud and L. de Sousa, 'Regional Parliaments in Europe and Latin America: Between Empowerment and Irrelevance', in A.R. Hoffmann and A. van der Vleuten (eds), Closing or Widening the Gap? Legitimacy and Democracy in Regional International Organizations (Aldershot: Ashgate, 2007), 92.
} 
parliamentary diplomacy and deliberation, ${ }^{96}$ since it upholds not only the principles of democracy and regional integration, but also those of nonintervention and self-determination, while condemning the use of force and promoting peaceful solutions to conflicts. $^{97}$ Similarly, besides supporting representative democracy, constitutional and parliamentary development in Latin America, Parlatino's purpose is to defend freedom, peace and security and suppress colonialism, imperialism and discrimination in all its guises. ${ }^{98}$ While currently an IPA, Parlatino is being considered as the parliamentary organ of the Community of Latin American and Caribbean States created in December 2011, 99 which would transform it into an IPO.

Another rather ambitious objective of Parlatino is to 'maintain relations with all parliaments of all geographical regions, as well as with international organisations'.100 Importantly, this includes relations with the EP, which were established in 1974 in the form of the EU-Latin American Interparliamentary Conference.101 This Conference, held every other year, helped tighten the historical, economic and cultural links between the European and Latin American regions and increase the parliamentarians' knowledge of the political systems of the partner region. ${ }^{102}$ The key role of the Conference was to promote democracy, human rights protection and development in Latin America on the basis of European experiences. ${ }^{103}$ The Conference also recurrently examined the problem of Latin American external debt. ${ }^{104}$ For all its lack of power and infrequent meetings, Parlatino was among the rare forums for the promotion of pan-Latin American consensus on the pacification of Central America and the resolution of conflicts in the region. ${ }^{105}$ In this context, Parlatino-EP cooperation substantially contributed to the development of the 'acquis' of EU-LAC relations. ${ }^{106}$

96 O. Costa and C. Dri, 'How Does the European Parliament Contribute to the EU's Interregional Dialogue?' in F. Baert et al. (eds), Intersecting Interregionalism: Regions, Global Governance and the EU (Dordrecht: Springer, 2014), 142.

${ }^{97}$ Art.2 Parlatino Institutionalisation Treaty of 16 November 1987.

98 Art.3(2), (4), (5), (7) and (9) of Parlatino Institutionalisation Treaty.

99 See www.cadenagramonte.cu/english/index.php/show/articles/5774:havana-hosts-meeting-of-latinamerican-parliament [Accessed 7 April 2014].

100 Art.3(11) Parlatino Institutionalisation Treaty.

101 M.L. Wiesebron, 'Co-operation between the European Union and Latin America: Privileged Relations?' in J. Grace (ed.), Los Nuevos Enfoques del la Integración: Más allá del Regionalismo (Quito: FLACSO, Ministerio de Cultura del Equador, 2008), 237.

102 Dri, 'Limits of the Institutional Mimesis of the European Union: The Case of the Mercosur Parliament' (2010) 1 Latin American Policy, 57.

103 M.L. Coral, 'El Diálogo Político como Pilar de las Relaciones entre la Unión Europea y América Latina: Reflexiones Sobre su Desarrollo y Contenido' (2007) 12 Oasis (Universidad Externado de Colombia), 485

104 Briefing note of the European Parliament on interparliamentary cooperation between the European Union and Latin America (1974-2003) of 3 April 2003 (update of the 1999 Working Document '25 years of interparliamentary cooperation between the European Union and Latin America', doc. no. POLI 107a $\mathrm{XX}), 13$.

105 S. Gratius and D. Nolte, 'Parlamento Transnacional e Integração: A Experiência do Parlamento Europeu e as Ligações que a América Latina Tem para o Mercosul' (2004) 1 Plenarium (Periodical of the Brazilian Chamber of Deputies), 88.

106 J.J.J.F. Fernández, 'La Asamblea Parlamentaria Euro-Latinoamericana (EuroLat) y la Dimension Parlamentaria de la Asociacíon Estratégica Birregional UE-LAC: Evolucíon y Perspectivas' Simposio sobre 
Still, although Conference meetings played a part in 'guiding the legislative acts and the political initiatives' of the EP towards Latin America, MEPs themselves recognise that this forum has 'little influence on parliamentary activity', which is why this forum focused on political dialogue and exchange of views more than on policy making and legislative initiatives. ${ }^{107}$ Nonetheless, the EP was seen in Latin America as a driver of bilateral relations, whereby MEPs sought to insert this region on the EU's Common Foreign and Security Policy agenda. ${ }^{108}$ The Conference was superseded by EuroLat.

\section{THE EU RETURNS DIRECTIVE: MULTILAYERED INTERNATIONAL PARLIAMENTS IN ACTION?}

The Returns Directive ${ }^{109}$ provides an excellent example of regulatory and legislative interdependence between the EU, Brazil and the Latin American region in general and of the way multilayered parliamentarism was employed to address the fallout created by the EU's enactment of politically sensitive policies in the field of immigration.

This Directive was fervently contested by many Latin American governments, regional organisations and parliamentary institutions. ${ }^{110}$ This, together with the concern expressed by the UN Human Rights Council over the protection of the fundamental rights of irregular migrants, was unprecedented in the history of EU legislation. 111 The two most controversial provisions were those foreseeing the possibility of detaining irregular third-country migrants for up to 18 months and of imposing a re-entry ban of up to five years. The Directive was adopted at first reading without a single amendment by the EP, which succumbed to the Council's pressure. ${ }^{112}$ This fact tarnished its democratic image and incurred international outcry. ${ }^{113}$ The two provisions were criticised not least by the Brazilian Congress,

las Relaciones Union Europea-América Latina: La Dimension Parlamentaria, VI Congreso CEIS AL, Toulouse, 1 July 2010, 3.

107 Dri, 'Limits of the Institutional Mimesis of the European Union: The Case of the Mercosur Parliament' (2010) 1 Latin American Policy, 64.

108 C.D. Martin, 'Las Relaciones América Latina-Unión Europea: Antecedentes de la Importancia e Institucionalización del Diálogo Político’ (2002) 22 Revista de Ciencia Política (Pontificia Universidad Católica de Chile), 52 and 62 .

109 Directive 2008/115/EC on common standards and procedures in Member States for returning illegally staying third-country nationals [2008] OJ L348/98.

110 J.A. Sanahuja, 'The European Union and Latin America: The Common Agenda after the Lima Summit' (2008) 7 ICEI Paper 3.

111 A. Baldaccini, 'The Return and Removal of Irregular Migrants under EU Law: An Analysis of the Returns Directive' (2009) 11 European Journal of Migration and Law, 2.

112 See further in: A.R. Servent, 'The European Parliament and the Returns Directive: The End of Radical Contestation; The Start of Consensual Constraints' in B. Anderson et al. (eds), The Social, Political and Historical Contours of Deportation (New York: Springer, 2013), 43-58.

113 D. Acosta, 'The Good, the Bad and the Ugly in EU Migration Law: Is the European Parliament Becoming Bad and Ugly?' (2009) 11 European Journal of Migration and Law, 22 and 38-39. 
Parlasur and Parlatino, all of which sent a strong message of indignation to the EU.

On 26 June 2008, a week after the EP's approval of the Directive, the Committee of Human Rights and Minorities of the Brazilian Chamber of Deputies adopted an Official Note against the Directive. ${ }^{114}$ Relying on the universality of human rights, this Note condemned it for colliding with the principles of coexistence, tolerance and prevalence of human rights, which constituted what was seen as a 'grave historical setback', given that millions of Europeans had settled in Latin America in the past 500 years. The Note warned that the Directive added to the losses caused by the EU's unfair commercial policies and subsidies. The Committee therefore requested the EP to reconsider and modify its decision. This came several months after the same Committee sought to discuss with the European and Spanish parliaments the increased deportation of Brazilians from EU ports of entry, especially the deportation from the Madrid airport of a Brazilian physics student intent on attending a conference in Lisbon. ${ }^{115}$ This affair was discussed in a public hearing in the Committee for External Relations and National Defence. ${ }^{116}$ The latter Committee also repudiated the Directive.117 Brazilian MPs criticised it in the plenary too. The Directive was called 'the Directive of Shame' for introducing the 'delict of immigration', which runs counter to the 1948 Universal Declaration of Human Rights, which, as customary international law, enshrines a right for everyone to leave his or her own country and freely move and reside within the borders of each state. ${ }^{118}$ Brazilian senators also reacted in the plenary invoking similar arguments and seeking further reflection on the Directive from the EU.119

Two days before the Chamber of Deputies issued its Official Note impugning the Directive, Parlatino adopted a declaration calling for a revision of the Directive so as to 'eliminate its eminently repressive character'. 120 Three days later, Parlasur followed suit with its own declaration rejecting the Directive as repugnant to human rights, calling upon the EP to review the Directive and inviting Mercosur

\footnotetext{
114 See http://www2.camara.leg.br/atividade-legislativa/comissoes/comissoespermanentes/cdhm/arquivos/nota-oficial-contra-lei-que-criminaliza-imigracao.pdf [Accessed 31 March 2014].

115 See http://agencia-camara.justica.inf.br/noticia/2008/03/comissao-deve-discutir-imigracaoparlamento-europeu [Accessed 31 March 2014].

116 See www.sindsprevri.org.br/jornal/secao.asp?area=24\&entrada=1886 [Accessed 31 March 2014].

117 Jornal da Câmara, Ano 9, No. 2061, 20 June 2008, 2.

118 See the intervention by Manuela d'Ávila MP in: Câmara dos Deputados, Plenario no. 159.2.53.0 of 2 July 2008, 134. See www.camara.leg.br/internet/plenario/notas/ordinari/V020708.pdf [Accessed 31 March 2014].

119 See the speech by senator Antonio Carlos Valadares in: Diário do Senado Federal no. 96 of 26 June 2008, 23839. See also the speech by Oto Agripino Maia, the then Undersecretary-General for Brazilian Communities Abroad in: Diário do Senado Federal no. 4 of 4 February 2010, 954.

120 Declaración de la Presidencia del Parlamento Latinoamericano sobre la directiva del Parlamento Europeo y del Consejo relativa a procedimientos y normas comunes en los Estados Miembros para el retorno de los nacionales de terceros países que se encuentren ilegalmente en su territorio of 24 June 2008, www.parlatino.org/es/presidencia/declaraciones-yresoluciones/declaraciones/660.html [Accessed 31 March 2014].
} 
governments to take 'corresponding measures'.121 The then Brazilian President of Parlasur, Dr. Rosinha, invoked the Latin American rejection of the Directive as an example of direct influence on intergovernmental decisions. ${ }^{122}$

Having incurred much international reprimand, the EP sought to appease Latin American concerns within EuroLat, whose co-presidents issued a joint statement on 14 July 2008 recommending to intensify interparliamentary dialogue through various existing channels. ${ }^{123}$ This was followed on 6 November 2008, for the first time, by the novel out-of-session discussions between, on the one hand, the EuroLat Executive Bureau accompanied by all other EuroLat members and, on the other hand, Jacques Barrot, the then Vice-President of the Commission, who was in charge of the Directive. ${ }^{124}$

Consequently, a working group on migration in EU-LAC relations (Working Group) was established within EuroLat in Madrid on 6 April 2009. The Working Group's aims were threefold: (a) to draw up fundamental principles for a biregional consensus on migration, allowing differentiated treatment when EU legislation is applied to Latin American and Caribbean migrants; (b) to monitor the transposition of the Returns Directive in the EU Member States; and (c) to encourage the establishment of a Euro-Latin American migration observatory. ${ }^{125}$ The Working Group was also to function as a watchdog taking stock of pending and future EU migration initiatives as well as of Latin American policies in this area. ${ }^{126}$ Some three months later, on 30 June 2009, a biregional intergovernmental dialogue on migration was launched. The Working Group thus had yet another impetus to accomplish its main objective, which was to draft recommendations for the next EU-LAC summit. This was completed on 15 May 2010 and the EU was strongly requested to ameliorate the legal regime of LAC migration. The Working Group warned that: "When transposing the Returns Directive, with which the LAC countries disagree, the EU Member States must retain the more favourable provisions already laid down in their domestic law'. ${ }^{127}$ It is notable that most

\footnotetext{
121 Declaración no. 20/2008 en defensa de los derechos humanos de los migrantes of 27 June 2008, www.parlamentodelmercosur.org/innovaportal/file/7493/1/decl.10 2008.pdf [Accessed 31 March 2014].

122 Jornal da Câmara, Ano 9, No. 2061, 20 June 2008, 2.

123 Comunicado de los co-presidentes da la Asamblea Parlamentaria Euro-Latinoamericana sobre la Directiva de retorno of $14 \quad$ July 2008, www.europarl.europa.eu/intcoop/eurolat/documents/declarations/directiva retorno 072008 es.pdf [Accessed 31 March 2014].

124 Fernández, 'La Asamblea Parlamentaria Euro-Latinoamericana (EuroLat) y la Dimension Parlamentaria de la Asociacíon Estratégica Birregional UE-LAC: Evolucíon y Perspectivas' Simposio sobre las Relaciones Union Europea-América Latina: La Dimension Parlamentaria, VI Congreso CEIS AL, Toulouse, 1 July 2010, 16.

125 Press $\quad$ release, Antigua Guatemala, 27 February 2009, www.europarl.europa.eu/intcoop/eurolat/documents/press statements/bureau antigua 2009 en.pdf

[Accessed 31 March 2014].

126 Minutes of the Working Group meetings of 6 and 7 April 2009, Spanish Congress of Deputies, Madrid, 2.

${ }^{127}$ EuroLat, Working Group Recommendation 'Migration in EU-LAC relations' of 15 May 2010, point r, 5 (emphasis added).
} 
recommendations were cast in strong peremptory language demanding resolutely for very specific action to be taken. This means that the Directive led to a hardening of EuroLat pronouncements, because these had thereto mainly taken the form of declarations of purpose containing rather loose and advisory prescriptions. ${ }^{128}$ The Working Group recommendations were sent inter alia to the Council of the EU, the Commission and all national parliaments of the EU Member States. In line with the recommendations, a message was sent to the $6^{\text {th }}$ EU-LAC summit, proposing to create a migration observatory for the EU-LAC area. ${ }^{129}$ In May 2011, the EP published its own study on such an observatory, which would harmonise databases, assess public policies and conduct research on migration. ${ }^{130}$ Although the purpose of the Working Group was fulfilled with the submission of the said recommendations, EuroLat authorised the continuation of its activities chiefly because the $6^{\text {th }}$ EU-LAC summit failed to address the issue of the observatory. The Working Group subsequently issued a joint proposal for the creation of the observatory in February 2012. Yet the activities of the Working Group go beyond this matter and its latest effort was to draft recommendations on impact of the economic and financial crises on EU-LAC migration. Ironically, the topicality of migration in biregional relations was proven in practice when certain Latin American representatives of EuroLat were reportedly subjected to discriminatory treatment when landing at Madrid and Frankfurt airports. ${ }^{131}$

Most recently, in March 2014 the Commission published a report on the EU return policy, which identified shortcomings in the implementation of the Returns Directive and called for special attention to be paid when implementing the provisions related to the detention of returnees, the treatment of minors and the corresponding safeguards and legal remedies, all of which were the object of criticism by Brazilian and other Latin American parliamentarians. Furthermore, although the report makes no specific mention of the Latin American 'uprising' against the Directive, the Commission acknowledged that an effective management of irregular migration flows requires a comprehensive approach, which necessitates an 'enhanced dialogue and cooperation with non-EU countries of origin' and the 'integration of foreign policy aspects into the EU migration policy and ensuring linkages between the internal and the external dimensions'.132 The EU executive hence recognised the impact of EU policy making on its international partners.

The developments surrounding the Returns Directive exhibit the escalation of parliamentary activity via numerous frameworks including both bilateral and

\footnotetext{
${ }^{128}$ S. Stavridis and N. Ajenjo, 'EU-Latin American Parliamentary Relations: Some Preliminary Comments on the EUROLAT' (2010) 10 Jean Monnet/Robert Schuman Paper Series, 14.

${ }^{129}$ EuroLat, Message to $6^{\text {th }}$ EU-LAC Summit, Madrid, 18 May 2010, 3.

${ }^{130}$ European Parliament, DG for External Policies, Proposal for the creation of an observatory for migration between the EU and Latin America and the Caribbean (authored by A. Ayuso and E. SánchezMontijano)

${ }^{131}$ Minutes of the Working Group meeting of 16 July 2013, Seimas, Vilnius, 2.

132 Communication of the European Commission to the Council and the European Parliament on EU return policy $\operatorname{COM}(2014) 199,7$.
} 
multilateral forums. The aftermath of the Directive caused 'parliamentary spillover' of policy monitoring, which gave rise to new interparliamentary channels to tackle what was perceived by Latin American parliamentarians as prejudicing the rights of many of their nationals. Acting in an international environment, Brazilian, other Latin American and European parliamentarians therefore engaged in norm entrepreneurship, trying to exert peer pressure on the EU in the direction of policy alteration. ${ }^{133}$ Yet migration is not the only area where parliamentary rapprochement could add value. The global financial and European debt crises as well as the differing macroeconomic policies of the EU and the Brazil provide fodder for interparliamentary liaison, not least to avoid 'mutual cognitive dissonance', whereby the EU is viewed as 'lecturing' Brazil on economics and banking. ${ }^{134}$ Such goal-oriented interaction among parliaments is applicable to any other region of the world.

\section{CONCLUDING REMARKS}

This article has argued that international parliamentarism does not evolve merely in the form of isolated international parliamentary bodies, but that cooperation between parliamentarians beyond domestic borders may be structured in layers, whereby parliaments and their members act within several international parliamentary forums in the same period regarding the same region. The multilayered character of international parliamentary activity was demonstrated using the example of the Latin American region and an in-depth case study of EUBrazil interparliamentary relations.

The preceding analysis shows that the layers of parallel parliamentary communication on diverse issues may furnish benefits for their participants that action within a single international interparliamentary framework might not. Opportunities for transferring knowledge and information both within one and the same participating parliament (e.g. among MEPs) and between two or more parliaments (e.g. between MEPs and Brazilian parliamentarians) are evident and they refer both to internal organisation and management and to interregional and global policy making. Intensified dialogue among parliamentarians may lead to the adoption of better policies domestically and a more coherent action globally.

While international parliamentary bodies are sometimes admonished for serving as nothing more than venues for political marketing, they do have their

\footnotetext{
133 See to this effect: Z. Šabic, 'International Parliamentary Institutions: A Research Agenda' in O. Costa et al. (eds), Parliamentary Dimensions of Regionalization and Globalization: The Role of Inter-Parliamentary Institutions (Basingstoke: Palgrave Macmillan, 2013), 21.

${ }^{134}$ M. Otero-Iglesias, 'The EU and Brazil: What Crisis? What Partner? What Strategy?' in G. Grevi and T. Renard (eds), Partners in Crisis: EU Strategic Partnerships and the Global Economic Downturn-ESPO Report no. 1 (FRIDE and Egmont: Madrid and Brussels, 2012), 20.
} 
own agendas and, although their pronouncements are as a rule not normative, they carry significant political value insofar as they influence the topics deliberated in the EP, which is manifested by the number of resolutions adopted on topics related to Latin America. ${ }^{135}$ The reverse influence is beyond doubt and, in the case of Mercosur, it has been widely acknowledged.

Where does this leave multilayered international parliamentarism and its utility for democratising international, interregional and domestic law and politics? Benefits are multiple and include increased policy deliberation, discussion and contestation, networking and socialisation, accumulation of knowledge and information, acquiry of skills, capacity building, assumption of joint positions, and the reduction of transnational regulatory irritants. However, even in a multilayered parliamentary world, constraints on the global action of parliamentarians, such as the lack of power to issue binding pronouncements, remain. Not only do these barriers diminish their clout, they limit their outreach to advocacy. Even so, concerted action by parliamentarians across a number of levels and within various frameworks might improve the prospects of influencing governmental actors and make them more accountable.

The responses of the Brazilian Congress, Parlatino, Parlasur, the EP and EuroLat to the Returns Directive exemplify the functioning, advantages and obstacles of multilayered international parliamentarism. The establishment and continued work of the EuroLat Working Group on EU-LAC Migration, as well as the push for the creation of a migration observatory, are distinct products of parliamentary diplomacy that aim to enable 'soft' democratic control over decisions of biregional interest. ${ }^{136}$ While parliamentary activism was triggered by the Returns Directive, it was soon decoupled from what became a veritable migration saga that caused parliamentarians to embark on a much wider investigation of biregional policy making. For the EP, increased contact with Brazilian and other Latin American parliamentarians can both further its democracy promotion agenda and fortify its position in the ongoing rivalry with the Commission and the Council in conducting EU foreign affairs. ${ }^{137}$ For the Brazilian Congress, intensified relations with MEPs represent a channel through which to voice their preoccupation over the EU's inconsistent treatment of Brazil as a Western Latin American country, a Mercosur member and a BRICS country, 138 and thus mitigate politico-economic friction while nurturing common understandings. This is all the more important because the EU is perceived in Brazil as both an opportunity as well as a challenge to the latter's national

\footnotetext{
135 Alles and Alles, 'La Cooperación Interparlamentaria Union Europea-Iberoamérica: Una Estrategia entre el Marketing Político y la Integración Birregional' in Europa-América Latina. Dos Caminos, ¿Un Destino Comun? (Santiago de Chile: RIL Editores, 2012), 60.

136 Minutes of the Working Group meeting of 17 May 2011, Montevideo, Uruguay, 3.

137 S. Gratius, 'EU Democracy Promotion in Latin America: More a Tradition than a Policy' (2011) 16 European Foreign Affairs Review, 692.

138 S. Gratius, 'Brazil and the European Union: Between Balancing and Bandwagoning' (2012) 2 ESPO Working Paper, 11.
} 
interest. ${ }^{139}$ Namely, during both Lula and Rousseff administrations, Brazil and the EU held conflicting views on trade and there was little overlap in their strategy preferences in multilateral international institutions. ${ }^{140}$ Closer parliamentary ties may contribute to reducing the negative consequences thereof. Significantly, the EU-Brazil interparliamentary partnership is indispensable for democratic legitimacy insofar as they engender new public spaces that 'play a critical role in setting limits on government, above and beyond those controls already enshrined in formal state institutions'. ${ }^{141}$

Finally, while inspired by their domestic electoral mandates and constitutional prerogatives, the roles that parliamentarians perform on the interregional and global plane are cast in 'soft' instruments, such as recommendations and messages. Rather than legislating, they advocate legal solutions. Instead of censuring governments, they exert pressure for policy change. Though the ultimate goal of international parliamentarism is to influence intergovernmental decision making, this is an inherently incremental process that is premised on a much more informal capacity to mobilise political support and steer policy development. ${ }^{142}$ In this regard, multilayered international interactions between parliamentarians facilitate the production of critical masses in favour or against certain policy enactments and, as such, feed the overall democratic process. In Habermas' vernacular, the discursive character of their opinion-formation unleashes 'the generative force of communicative freedom', ${ }^{143}$ which helps shape the public sphere and the democratic frame of lawmaking.

In the global arena, the greatest contribution of parliaments to democracy is to facilitate the public exposure of contested decisions, whereby elected officials discuss and publicise their vices and virtues in an exchange of policy-oriented arguments. The parliaments' chronic lack of 'hard' constitutional powers of legislation and accountability in the international sphere shifts focus towards deliberation as the substantive element of the political process. To the extent that this constitutes political constraint, it is possible to conceive of multilayered international parliamentarism as the nucleus of a rudimentary and composite form of proto-global parliamentarism and constitutionalism.

\footnotetext{
139 A. Poletti, 'The EU for Brazil: A Partner towards a 'Fairer' Globalization?' (2007) 12 European Foreign Affairs Review, 283.

140 M.G. Saraiva, 'Brazil's Strategies and Partnerships: The Place of the European Union' (2012) 20 Perspectives: Review of International Affairs, 59.

${ }_{141}$ M.A. Garcia, 'The Strategic Partnership between Brazil and the European Union' in G. Grevi and A. de Vasconcelos (eds), Chaillot Paper No. 109 Partnerships for Effective Multilateralism: EU Relations with Brazil, China, India and Russia (EUISS: Paris, 2008), 57.

142 This could be likened to the 'external deliberation' function of parliaments in general. See V.A. da Silva, 'Deciding without deliberating' (2013) 11 International Journal of Constitutional Law, 564.

143 J. Habermas, Between Facts and Norms: Contributions to a Discourse Theory of Law and Democracy (Cambridge MA: MIT Press, 1996), 151.
} 